\title{
EFFECTS OF MINERAL SUBSTANCES WITH A BUFFERING EFFECT ON MILK PRODUCTION AND MILK COMPOSITION IN HEAT STRESS CONDITIONS
}

\author{
Milan Adamović ${ }^{1}$, Horea Šamanc ${ }^{2}$, Ivan Vujanac ${ }^{2}$, Olivera Valčić ${ }^{2}$, Danijela Kirovski ${ }^{2}$ \\ ${ }^{1}$ Institute for Technology of Nuclear and Other Mineral Raw Materials, Belgrade, Serbia \\ ${ }^{2}$ Belgrade University, Faculty of Veterinary Medicine, Belgrade, Serbia \\ m.adamovic@itnms.ac.rs
}

\begin{abstract}
This paper presents the results of investigations on the effects of a mineral mixture with a buffering effect, (bentonite, zeolite, magnesium oxide and sodium bicarbonate), on the quantity and composition of milk, $\mathrm{pH}$ value of cow's rumen contents, number and motility of microorganisms. The study was conducted from June to November on two groups of cows: the control - C (129) and experimental - E (119). The investigated mineral mixture was included in the complete feed mixture $(1 \%)$. The milk yield during the hottest summer months (June - August) in the group E was higher by $1.99 \mathrm{~kg}$ or $8.16 \%(\mathrm{p}<0.05)$. During the period from September to November the milk yield in this group was also higher, but insufficiently to make the difference $(0.38 \mathrm{~kg}$ or $1.53 \%)$ between the $\mathrm{C}$ and $\mathrm{E}$ groups $(p>0.05)$. The yield of milk was higher in the group E by $1.19 \mathrm{~kg}$ or $4.85 \%(p<0.05)$ for the duration of the experiment from June to November. The differences in the content and yield of milk fat and protein, $(\%$ and $\mathrm{kg})$ were insignificantly higher for the group $\mathrm{E}$ during both investigation periods. The $\mathrm{pH}$ value of the rumen content was higher in the group $\mathrm{E}$ and was within the optimal physiological limits. Before the morning meal the values for the groups $\mathrm{C}$ and E were 6.25 and $6.79(\mathrm{p}>0.05)$, respectively. After the morning meal the corresponding rumen $\mathrm{pH}$ values were 6.01 and $6.92(\mathrm{p}<0.05)$. The number and motility of the infusoria present in the rumen of the group E cows was increased. The studied mineral mixture has a positive effect on the $\mathrm{pH}$ stability and development of the microorganisms present in the rumen under conditions of heat stress. This contributes to the arousal of favorite conditions for food digestion and utilization and hence to higher milk production and increased fat and protein content.
\end{abstract}

Key words: acidosis; cow; rumen; buffer

\section{ЕФЕКТИТЕ ОД МИНЕРАЛНИТЕ МАТЕРИИ СО ПУФЕРЕН ЕФЕКТ ВРЗ ПРОИЗВОДСТВОТО НА МЛЕКО И НЕГОВИОТ СОСТАВ ВО УСЛОВИ НА ТОПЛОТЕН СТРЕС}

Во овој труд се презентирани резултатите од истражувањето за ефектите на минерални смеси со пуферен ефект (бентонит, зеолит, магнезиумоксид, натриумбикарбонат), врз количеството и составот на млекото, рН-вредноста на содржината на руменот кај крави, како и врз бројот и подвижноста на микроорганизмите. Истражувањето беше спроведено од јуни до ноември на две групи крави: контролна - C (129), и експериментална - Е (119). Истражуваната минерална смеса беше додадена во комплетната гранителна смеса (1\%). Приносот на млеко во текот на најжешките летни месеци (јуни-август) во групата $\mathrm{E}$ беше повисок за $1,99 \mathrm{~kg}(8.16 \%)(\mathrm{p}<0,05)$. Во текот на периодот септември-ноември приносот на млеко во оваа група исто така беше повисок, но недоволен за да се направи разлика $(0,38 \mathrm{~kg}$, или $1,53 \%)$ помеѓу групите С и $\mathrm{E}(\mathrm{p}>0,05)$. Приносот на млеко во групата $\mathrm{E}$ беше повисок за $1,19 \mathrm{~kg}$, или 4,85\% $(\mathrm{p}<0,05)$ за цело време на траењето на експериментот (јуни-ноември). Разликите во содржината и приносот на млечни масти и протеини (во \% и $\mathrm{kg}$ ) беа незначително повисоки во групата Е во текот на двата истражувачки периода. Вредноста на $\mathrm{pH}$ на содржината на руменот беше повисока во групата $\mathrm{E}$, но во рамките на оптималните физиолошки граници. Пред утринскиот оброк вредностите за групите С и Е беа 6,25 и 6,79 (p>0,05), соодветно. По утринскиот оброк соодветните $\mathrm{pH}$-вредности на руменот беа 6,01 и 6,92 (p<0,05). Бројот и подвижноста на инфузории во руменот на кравите од групата Е се зголеми. Истражуваната минерална смеса има позитивен ефект врз стабилноста на $\mathrm{pH}$ и развојот на микроорганизмите присутни во руменот во услови на топлотен стрес. Ова придонесува за поттикнување погодни услови за варење и користење на храната, а тоа значи повисоко производство на млеко и зголемување на содржината на масти и протеини во него.

Клучни зборови: ацидоза; крава; румен; визуелен ефект 


\section{INTRODUCTION}

Disorders in the process of food digestion in the rumen often manifest as acidosis which leads to a number of pathological processes among which are morphological changes of the rumen mucosa, decreased motility, poor food passage, as well as ruminitis and parakeratosis. As a result of the above mentioned is a significantly decreased resorptive surface of the rumen and reduced absorption of the products of food digestion. Their hindered input can jeopardize the metabolic balance, above all the stability of energy metabolism. Bearing in mind that acidosis is accompanied by poor appetite it is clear that the end result of these disorders is a reduction in milk production.

Rumen acidosis is characterized by an excessive accumulation of lactic acid as the result of a diet rich in easily digested carbohydrates, excessive acidic and moist feeds, insufficient fibers in the diet, few meals and long periods between meals. In such cases there is insufficient production of saliva, which is the natural regulator of the electrochemical reaction in the rumen. These problems are specially enhanced in high yielding dairy cows in the first phase of lactation when they have to consume large quantities of concentrated feeds and in the summer months, especially when kept in tie stalls when high ambient temperatures and inadequate microclimate in the stable result sudden appetite loss. Besides, during the high summer temperatures food is at a higher risk to become spoiled, silage ferments, moulds which produce mycotoxins are produced and rumen microflora is negatively affected which makes the problem even worse.In the state of acidosis the number of bacteria producing lactic acid in the rumen progressively increase, and the number of bacteria which use up this acid is on the decrease. Streptococcus bovis produces lactic acid in the process of carbohydrate metabolism and quickly becomes the dominant microorganism in the rumen's content.During this process the number of Megasphera elsdenii, Selenomonas ruminantium and other bacteria which use lactic acid is on the decrease. By further lowering the electrochemical reaction the reproduction of Streptococcus bovis decreases and lactobacilli continue to produce lactic acid thus contributing to a further increase in its concentration in the rumen. The lowest $\mathrm{pH}$ values in the rumen are recorded during night time and in the early morning hours. The deviation of the $\mathrm{pH}$ value from its normal physiological range (6.2-
6.8) results in an adverse impact on the development of the rumen microflora and thus the processes of digestion, which negatively affects the production and fat content in the milk (Horea et al., 2006)

The key factor for the preservation of the $\mathrm{pH}$ balance of the rumen is the bicarbonate buffer. However, under conditions of rumen acidosis there is a decreased production of saliva and hence less bicarbonate reaches the rumen. The efficacy of the bicarbonate is then almost negligible due to the present atonia of the rumen and insufficient mixing of the saliva and rumen content. Due to the state of atonia there is a decreased degree of resorption of acids and the role of the bicarbonate buffer is almost minimized. Under conditions of heat stress, during high summer temperatures $\left(>27^{\circ} \mathrm{C}\right)$ due to panting there is increased Salivation which results in a loss of calcium, potassium, sodium and magnesium cations which are necessary for the maintenance of the acid-base status of the animal (Vujanac et al., 2011).

Buffers which have the capability to neutralize the increased acidity are used for the maintenance of the rumen's $\mathrm{pH}$. Some minerals, such are bentonite and zeolite belong to the group of natural alumosilicates which have a marked surface activity which is the result of superficial electricity. Their chemical activity can be controlled and directed, which gives them the chance to be applied in the diet of domestic animals. Both of these minerals act as buffers. In an acidic environment by cation exchange they bind $\mathrm{H}^{+}$and release a cation which is naturally found in an exchangeable position, thus resulting in increased $\mathrm{pH}$. These changes occur only as long as the neutral environment $(\mathrm{pH}$ 7) is achieved. When the $\mathrm{pH}$ is over $\mathrm{pH} 7$, the presence of these minerals leads to a decrease in $\mathrm{pH}$ down to the neutral stage. Rivera et al. (2002) have confirmed that zeolite has a tendency to neutralize the water solutions, regardless if it serves as a donor or acceptor of protons, which indicates its amphoteric character. The use of only magnesium oxide or sodium bicarbonate can result in an increased rumen $\mathrm{pH}$ which is not desirable. After their reduction in the rumen there is a subsequent $\mathrm{pH}$ decrease below optimal values. The application of a mixture containing bentonite, zeolite, magnesium oxide and sodium bicarbonate creates conditions for the maintenance of a stable $\mathrm{pH}$ in the rumen within the optimal range for a period of 24 hours. Besides this, these substances show other useful effects. Magnesium oxide enhances the ab- 
sorption of acetic acid. Bentonite and zeolite successfully absorb micotoxins (aflatoxin), excess ammonia, heavy metals, radio nucleotides and excess water. Bentonite swells and thus slows food passage through the digestive tract which results in its improved digestion and utilization. Such additives are added to the feed mixture in a quantity of $1-2 \%$. (Garicia Lopez, 1992; Vicini et al., 1988; Eng et al., 2002; Nikkah et al., 2000; Adamović et al., 2003; Petrujkić et al., 2010; Radivojević et al.,2010 and others).

\section{MATERIAL AND METHODS}

The study was conducted from June to November on two groups of cows: the control - C (129) and experimental - E (119). The experiment was carried out on the Padinska Skela property which is part of the PKB Corporation. The cows were in a linked system of keeping. Groups were formed according to "couple" system (two cows with similar characteristics) after 7-10 days calving and alloted to one of two stables. The given meals were identical with the difference that in the complete feed mixture in the group $\mathrm{E}$ a mineral supplement with buffering propreties was added in the quantity of $1 \%$. The mixture was produced at the Institute for Technology of Nuclear and Other Mineral Raw Materials, Belgrade, Serbia (commercial name Mix Plus). The mixture composition is based on magnesium oxide, sodium bicarbonate, bentonite and zeolite. Cows were fed twice a day (6-7 AM and 5-6 PM). Feedstuff composition based on the proportion of dry matter of individual feeds in dry matter of the given meal, chemical composition of the meal, and composition of complete feeds are given in Tables 1-3. Extruded soybeans were given separately, an average of 1.5 $\mathrm{kg} / \mathrm{cow} /$ day. Concentrate was standardized to the amount of $300 \mathrm{~g} / \mathrm{kg}$ of milk. Control of milk yield and determination of the chemical composition of milk was carried out once a month. The balance of cations and anions in the meals (BAKO) was determined using the formula proposed by (Beed, 1992):

$$
\begin{gathered}
\mathrm{BKAO} \mathrm{mEq} / \mathrm{kg} \mathrm{SM}=[(435 \times \% \mathrm{Na})+ \\
(256 \times \% \mathrm{~K})]-[(282 \times \% \mathrm{Cl})+(624 \times \% \mathrm{~S})]
\end{gathered}
$$

Feed consumption was estimated daily. The $\mathrm{pH}$ of the rumen content was measured at the end of the trial. Samples of ruminal contents were collected by probe $0.5 \mathrm{~h}$ before morning feeding and
$5 \mathrm{~h}$ after the morning feeding from 10 cows in each group. The electrochemical reaction in the samples of rumen contents was measured by a $\mathrm{pH}$ meter (WTW 330i) immediately after sampling. Chemical analysis of the milk samples was performed with an automatic machine Milkoscan.

The air temperature was measured daily (1-2 PM) with a mercury thermometer. Outdoor temperature was measured in the shade at 10 meters distance from the stables at a height of $150 \mathrm{~cm}$ from the soil, and the stable temperature was recorded in the middle of the building, at $100 \mathrm{~cm}$ above the feeding table.

\section{Table 1}

Percentage of dry matter in dry matter of complete feed meal, \%

\begin{tabular}{lcc}
\hline \hline Indicator & C group & E group \\
\hline Alfalfa hay & 17.35 & 16.59 \\
Alfalfa haylage & 11.09 & 10.90 \\
Corn plant silage, 30\% DM & 28.61 & 29.71 \\
Brewer's trope & 3.73 & 3.57 \\
Extruded soybean & 6.81 & 6.51 \\
Complete feed mixture C & 32.41 & - \\
Complete feed mixture E & - & 32.72 \\
\hline Total & 100.00 & 100.00 \\
\hline \hline
\end{tabular}

Table 2

Chemical composition and cation and anion content in the meals

\begin{tabular}{lcc}
\hline \hline Indicator & C group & E group \\
\hline Dry matter in the meal,\% & 49.55 & 49.24 \\
Dry matter, kg & 19.82 & 20.73 \\
NEL, MJ & 127.58 & 132.89 \\
Proteins, \% DM & 16.65 & 16.78 \\
Fats, \% DM & 4.43 & 4.39 \\
Cellulose, \% DM & 18.06 & 17.85 \\
Ca, \% DM & 0.89 & 0.91 \\
P, \% DM & 0.66 & 0.65 \\
K,\% DM & 1.50 & 1.48 \\
Na,\% DM & 0.13 & 0.15 \\
Mg,\% DM & 0.34 & 0.39 \\
Cl,\%DM & 0.45 & 0.44 \\
S,\% DM & 0.30 & 0.29 \\
BAKO mEq g/DM & +126.45 & +139.09 \\
\hline \hline
\end{tabular}


Table 3

\begin{tabular}{lcc}
\multicolumn{3}{c}{ Composition of complete feed mixtures } \\
\hline \hline Indicator & C group & E group \\
\hline Corn grain groats & 26.30 & 26.30 \\
Oat grain groats & 20 & 20 \\
Sunflower meal & 42 & 42 \\
Flour meal & 8 & 7 \\
Dicalcium phosphate & 1.40 & 1.40 \\
Chalk & 1.60 & 1.60 \\
Vitamin \& mineral mixture & 0.70 & 0.70 \\
Mix Plus & 0 & 1 \\
Total & 100 & 100 \\
NEL, MJ & 5.98 & 5.92 \\
Total protein & 18.68 & 18.54 \\
\hline \hline
\end{tabular}

Statistical data analysis was done with StatSoft. Inc.: Statistica. Data Analysis Software System. Version 8.0, 2008.

\section{RESULTS AND DISCUSSION}

Differences between the diets for the groups $\mathrm{C}$ and $\mathrm{E}$ during the experiment were negligible and it can be stated that they were isoenergetic and isoproteinic. The difference was evident for the concentrations of anions and cations (BKAO) which was higher for the group $\mathrm{E}$ and measured for C:E 126,45:139.09 $\mathrm{mEq} \mathrm{g} / \mathrm{DM}$. The value for the group $\mathrm{E}$ was at the same time closer to the optimal BKAO value for mid-lactation cows (100200 days) included in both groups $\mathrm{C}$ and $\mathrm{E}$.

Previous studies confirmed that consumption of DM, water and milk production increase as BKAO increases in the meals for lactating cows. BKAO values in the experimental group in the described trial are close to the values reported by Delaquis and Block (1995); Tucker and al. (1988), West (1993) and others which are considered acceptable for the mid lactation period $(+150$ to $+250 \mathrm{mEq} \mathrm{g} / \mathrm{DM}$ ). According to the above authors maintenance of the high anion-cation difference, with higher cation values is necessary as $\mathrm{Na}^{+}$and $\mathrm{K}^{+}$to prevent $\mathrm{pH}$ decrease and acidosis. Cows fed meals with a positive BKAO $(+200 \mathrm{mEq} / \mathrm{kg} \mathrm{SM})$ produced more milk than cows fed a diet with a negative BKAO $(-100 \mathrm{mEq} / \mathrm{kg} \mathrm{SM}) \cdot \mathrm{pH}$ values of the blood and urine, as well as $\mathrm{HCO}_{3}^{-}$concentrations linearly increased with increasing BKAO values.

The milk yield in the period from June to August (Table 4) in the group E was higher by 1.99 $\mathrm{kg}$ or $8.16 \%(\mathrm{p}<0.05)$. For the same period a relative $(\%)$ and absolute $(\mathrm{kg})$ increase in the fat content and produced fats and proteins in the milk $(p>0.05)$ was recorded. The average outdoors air temperature between $1-2 \mathrm{PM}$ was $32^{\circ} \mathrm{C}$ and the temperature in the stables was $36^{\circ} \mathrm{C}$

Table 4

Milk yield and composition of milk during the period from June to August

\begin{tabular}{lccc}
\hline \hline Indicator & C group & E group & $\mathrm{C}=100$ \\
\hline Milk yield, kg/cow/day & 24.36 & $26.35^{*}$ & 108.16 \\
Milk fat, \% & 3.31 & 3.40 & 102.71 \\
Milk fat, kg/day & 0.81 & 0.89 & 109.87 \\
Protein, \% & 2.80 & 2.84 & 101.43 \\
Protein, kg/dan & 0.68 & 0.75 & 110.29 \\
\hline \hline
\end{tabular}

${ }^{*}(\mathrm{p}<0.05)$

The milk yield in the period from September to October in the group E (Table 5) was higher by $0.38 \mathrm{~kg}$, or $1.53 \%(0<0.05)$. Differences between the groups $\mathrm{C}$ and $\mathrm{E}$ were significantly smaller. The quantity of produced milk fats and proteins in this period was, as in June - August insignificantly higher in the group E ( $>0.05)$. The average outdoor air temperature for the period between 1-2 PM was significantly lower compared to the previous period and measured $21^{\circ} \mathrm{C}$, the stable air temperature was $25^{\circ} \mathrm{C}$.

\section{Table 5}

Milk yield and composition of milk during the period from September to November

\begin{tabular}{lccc}
\hline \hline Indicator & C group & E group & $\mathrm{C}=100$ \\
\hline Milk yield, kg/cow/day & 24.76 & 25.14 & 101.53 \\
Milk fat, \% & 3.33 & 3.49 & 104.80 \\
Milk fat, kg/day & 0.82 & 0.88 & 107.32 \\
Proteins, \% & 2.92 & 2.93 & 100.34 \\
Proteins, kg/day & 0.72 & 0.74 & 102.77 \\
\hline \hline
\end{tabular}

The milk yield during the period from June to November, and the entire trial period (Table 6) 
was higher in the group E by $1.19 \mathrm{~kg}$, or $4.85 \%$ $(p<0.05)$. The quantity of produced milk fat and protein was not significantly higher in the group $\mathrm{E}$ $(\mathrm{p}>0.05)$.

Table 6

\section{Milk yield and composition of milk during} the period from June to November

\begin{tabular}{lccc}
\hline \hline Indicator & C group & E group & $\mathrm{C}=100$ \\
\hline Milk yield, kg/cow/day & 24.56 & 25.75 & 104.85 \\
Milk fat, \% & 3.32 & 3.45 & 103.91 \\
Milk fat, kg/day & 0.81 & 0.89 & 109.88 \\
Proteins, \% & 2.86 & 2.89 & 101.05 \\
Proteins, kg/day & 0.70 & 0.74 & 105.71 \\
\hline
\end{tabular}

Comparing the results achieved in the produced quantity of milk in the period from June to August and September to November it can be concluded that the studied mineral mixture (with buffering action) effectively influenced the milk yield of cows in the warmest period of the year, when the cows were apparently exposed to the impact of heat stress as evidenced by temperatures which were above $27^{\circ} \mathrm{C}$ for a longer period of time.

Nikkhah et al. (2001), found that the use of zeolite and sodium bicarbonate in the diet of cows individually or in combination, increases the milk yield by $0.7-2 \mathrm{~kg}(\mathrm{p}<0.05)$, while fat and protein in the milk increased by 0.12 to 0.26 , respectively, equivalent to 0.04 to 0.06 percentage points. According to Adamović et al. (2003), the addition of mineral mixtures based on magnesium oxide, sodium bicarbonate, bentonite and organozeolite (modified natural zeolite) in the first 100 days of lactation cows influenced the increase of milk yield, corrected to $4 \%$ milk fat, by $0.43 \mathrm{~kg} /$ day or $1.59 \%$. The average milk fat content in milk was higher in the experimental group by 0.29 percentage points (3.29 and 3.58\%). Horea et al. (2006) when using the same mineral mixture as in the present study, found milk production to be increased by $1.5 \mathrm{~kg} /$ day or $6.17 \%$ with an increase in the milk fat content from 3.39 to $3.53 \%$, and a slight increase of protein from 2.88 to $2.89 \%$. Similar results in terms of milk yield when using mineral mixtures of the same composition were recorded by Petrujkić et al. (2010). In doing so, the differ- ences in the quantity of milk between the control and experimental groups of cows $\left(30^{\text {th }}, 60^{\text {th }}\right.$ and $90^{\text {th }}$ day of the trial) were statistically significant $(p<0.05)$. Bergero et al. (1995) found that the addition of $250 /$ head/day of zeolite (clinoptilolite $64 \%$ ) in the diets of cows increased the amount of milk by $1.47 \mathrm{~kg}$ /day or $12.47 \%$, but did not have a major influence on the $\mathrm{pH}$ of the rumen contents, the amount of ammonia and content of volatile fatty acids present in the rumen. The results given by Moghaddam i Taghizadeh (2001) should be emphasized as they studied the effects of $1.8 \%$ and $3 \%$ zeolite in the meal DM during a 21 day trial on dairy cows. The authors determined a significant decrease in rumen $\mathrm{pH}$ (from 6.78 to 6.71 and 6.34). Results of the effects of mineral mixture with buffering effect (of the same composition, with the same rations and cows, as in our research,) on the $\mathrm{pH}$ of the rumen contents of cows were reported by Horea et al. (2006) (Table 7).

Table 7

Rumen $\mathrm{pH}$ values

\begin{tabular}{lccc}
\hline \hline Time of sampling & C group & E group & Significance \\
\hline 0.5 h before feeding & $6.25 \pm 1.5$ & $6.79 \pm 0.89 *$ & $\mathrm{p}<0.05$ \\
5 h after feeding & $6.01 \pm 2.8$ & $6.92 \pm 1.01 *$ & $\mathrm{p}>0.05$ \\
\hline \hline
\end{tabular}

According to the research done by the authors the investigated use of mineral mixture had a beneficial effect on the $\mathrm{pH}$ of the rumen contents before (6.79) and after the morning feeding (6.92). This clearly shows that the presence of mineral mixture in the rumen contents maintained a stable electrochemical reaction continuously within the physiological range. Also in this group of cows there were small individual differences, which was not the case with cows in the group $\mathrm{C}$, where the $\mathrm{pH}$ of the rumen content was below the physiological limits and was 6.25 before feeding and 6.01 after feeding. In such cases the animals did not take enough food in the morning and usually large amounts of food were left over up to the next meal. Similar results, when using the same mineral mixture in the diet of cows in early lactation, were found by Adamović et al. (2003) and Vujanac et al. (2005). Nikkhah et al. (2001) found that zeolite and sodium bicarbonate, administered simultane- 
ously, increased the $\mathrm{pH}$ in the rumen liquor from 6.16 to 6.50 . Similar results were determined by Petrujkić et al. (2010) as well. The pH of the rumen contents of the control and experimental groups of cows on the $60^{\text {th }}$ day was 6.22:6.77 and on the $90^{\text {th }} 6.31: 6.68$, whereas the differences were statistically significant $(\mathrm{p}<0.05)$.

In addition to qualitative and quantitative changes in the bacterial flora in the rumen, the low $\mathrm{pH}$ affects the abundance and mobility of infusoria in the rumen (Nocek, 1997). In the study conducted on the native rumen contents significant differences between the presence of infusoria between the group $\mathrm{C}$ and $\mathrm{E}$ were found. Cows in the group $\mathrm{C}$ had significantly fewer infusoria in the visual field small and medium-sized $(n=8)$, and the number of large infusoria in the visual field was very small (1 to 2 ). In the group $E$ of cows three times more infusoria in the visual field (24) was found and all three types were present: small, medium and large. Unlike cows in the group C, where the infusoria of the rumen contents were poorly motile, cows infusoria in group $\mathrm{E}$ were very mobile. Radivojević et al. (2010) used a similar mineral mixture in the experimental group of cows and found a higher $\mathrm{pH}$ value of rumen contents and a number of medium and large infusoria.

\section{CONCLUSION}

The quantity of milk in the hottest summer months (June - August) in the group E was higher by $1.99 \mathrm{~kg}$ or $8.16 \%(\mathrm{p}<0.05)$. In the period from September to November the quantity of milk the in group E also increased, but differences between groups of $0.38 \mathrm{~kg}$ or $1.53 \%$ in favor of group E were lower $(p>0.05)$. The quantity milk for the period from June to November was higher in the group E by $1.19 \mathrm{~kg}$ or $4.85 \%(\mathrm{p}<0.05)$. In the same period, the differences in content and amount of milk fat and protein were slightly higher in the group $\mathrm{E}(\mathrm{p}>0.05)$.

The $\mathrm{pH}$ of the rumen was higher in the group $\mathrm{E}$, and before the morning feeding it was 6.25 and $6.79(\mathrm{p}>0.05)$, or after the morning feeding 6.01 and $6.92(p<0.05)$. In the rumen in the experimental group an increased number of infusoria with greater mobility was described. It can be concluded that the investigated mineral mixture has a positive impact on the stability and the $\mathrm{pH}$ of the rumen microbial growth, which contributes to the creation of favorable conditions for the digestion and feed utilization, and thus greater milk yield and production of milk fat and protein. This effect is more favorable when the animals are under conditions of heat stress caused by high external temperatures, reaching a value of over $27^{\circ} \mathrm{C}$.

Acknowledgement: This study was realized within the TR 31003 project framework, supported by the Ministry of Education and Science, Republic of Serbia.

\section{REFERENCES}

[1] Adamović, M., Tomašević-Čanović, Magdalena, Daković, Aleksandra, Lemićm J., Grubić, G., Adamović, O., Stojanović, B., Radivojević, M. (2003): Uticaj mineralnih materija sa pufernim dejstvom na proizvodnju i sastav mleka. X Simpozijum »Tehnologija hrane za životinje«, V. Banja, pp. 133-148.

[2] Beede, D. K. (1992), The Dcad concept Transition rations for dry pregnant cows. Feedst. 64, 12.

[3] Bergero, D., Rummelo, G., Sarra, C., Angelo, D. (1995): Efect of Natural Clinoptilolite or Phillipsite in the Feeding of Lactating Dairy Cows. Meeting Natural Zeolites, Sofia. pp. 67-72.

[4] Delaquis, A. M., Block E. (1995): Dietary cation-anion difference, acid-base status, mineral metabolism, renal function, and milk production of lactating cows. J. Dairy Sci., 78, 2259-2284.

[5] Eng, K. S., Bechtel, R. R., Hutcheson, D. (2002): Ading a potasium clinoptilolite zeolite to feedlot rations to reduce manure nitrogen losses and its impact on rumen Ph, Ecoli and performance. Pres. Eng. Inc., San Antonio, Texas, 15-25.

[6] Garicia R. Lopez, Elias, A., Menchaca, M. A. (1992): The utilization of zeolite by dairy cows. II. Effect on milk composition, Cuban. J. Agric. Sci., 26:131.

[7] Moghaddam, G., Taghizadeh, A. (2001): Effect of zeolite nutrition on rumen ecosystem in dairy cow. Dep of Animal science, Faculty of Agriculture, University of Tabriz, Tabriz, Iran. $\quad$ www.bsas.org.uk/downloads/annlproc/Pdf 2001/155.pdf.

[8] Nikkah, A., Goodarzi, N., Ashtiani, Miraie (2000): The use of Zeolite in the ration of lactating Holstein dairy cow andd its effect on milk yield and composition. Iranian Journal of Agricultural Sciences, Vol. 31. Teheran.

[9] Nikkhah, A., Safamehr, R., Moradi, M. (2001): Effect of natural clinoptilolite - rich tuf and sodium bicarbonate on milk yield, milk composition and blood profile in Holstein cows. Vol. 135. Elsevir edition. $13^{\text {th }}$ Intern. Zeolite Conf., Zeolites and mesoporus materials at the dawn of the 21st century, Montpellier, France.

[10] Nocek, J. E. (1997): Bovine acidosis: Implications on laminitis. J. Dairy Sci., 80, 1005-1028.

[11] Petrujkić Branko, Šamanc Horea, Adamović Milan, Stojić Velibor, Petrujkić Tihomir, Grdović Svetlana, Šefer Dragan, Marković Radmila (2010): Effects of feeding buffering mineral mixture on subacute rumen acidosis 
and some production traits in dairy cows. Japanese Journal of Veterinary Research, Vol. 58, No 3\&4, [6], pp 171-177.

[12] Radivojević, M., Adamović, M., Šamanc, H., Radomir, B., Protić, G. (2010): Efikasnost mineralnih materija u saniranju i preveniranju kiselih indigestija buraga krava. Zbornik naučnih radova, Vol. 16, br. 3-4, 61-70.

[13] Rivera, A., Rodrigez-Fuentes, G., Altshuler, E. (2002): Time evaluation of natural clinoptilolite in aqueus medium conductivity and $\mathrm{pH}$ experimsnts. Microporus and Mesoporus Materials, 40, 173-179.

[14] Statsoft. Inc., Statistica. Data Analysis Software System. Version 8.0, (2008): Available from http://www.statsoft. $\mathrm{com} /$

[15] Šamanc, H., Stojić, V., Adamović, M., Vujanac, I., Petrujkić, B. (2006): Acidoza buraga: Mogućnost preveniranja korišćenjem mineralnih predsmeša sa pufernim dejstvom. Veterinarski glasnik, Vol. 60, br. 1-2, 11-19.

[16] Tucker, W. B., Harrison, G. A., Hemken, R. W. (1988): Influence of dietary cation-anion balance on milk, blood, urine and rumen fluid in lactation dairy cows. J. Dairy Sci., 71, 346.

[17] Vujanac Ivan, Kirovski Danijela, Šamanc, H., (2011): Prodanović, R., Lakić, N., Adamović, M., Valčić, O. Milk production in high-yielding dairy cows under different environmental temperatures, Large Animal Review, $18,1,31-36$.

[18] Vujanac, I., (2005): Adamović, M., Šamanc, H., Petrujkić, B., Dimitrijević, B. Preveniranje kiselih indigestija goveda primenom mineralnih materija regulatora elektrohemijske reakcije sadržaja buraga. $7^{\text {th }}$ Clinica Veterinaria, 284-288, Ohrid.

[19] Vicini, J. L., Cohick, W. S., Clarrk, J. H., Mc Cutcheon, S. N., Bauman, D. E. (1988): Effects of feed intake and sodium bicarbonate on milk production and concetrations of hormones and metabolites in plasma of cow. J., Dairy Sci. 71:1232.1

[20] West, J. W. (1993): Cation-anion balance: Its role in lactating cow nutrition. Feedstuffs, No 10:14-15. 